\title{
Effect of Water Content and MgO / ADP Ratio on the Properties of Magnesium Phosphate Cement
}

\author{
Daniel Véras Ribeiro * (D), Gustavo Rocha de Paula ${ }^{b}$, Marcio Raymundo Morellib \\ ${ }^{a}$ Universidade Federal da Bahia, Departamento de Ciência e Tecnologia dos Materiais, Rua Aristides \\ Novis, 02, Federação, 40210-630, Salvador, BA, Brasil \\ ${ }^{b}$ Universidade Federal de São Carlos, Departamento de Engenharia de Materiais, Rodovia Washington \\ Luis, Km 235, 13565-905, São Carlos, SP, Brasil
}

Received: January 14, 2020; Revised: May 02, 2020; Accepted: May 21, 2020

\begin{abstract}
Materials such as magnesium phosphate cement (MPC) have attracted significant attention of researchers, therefore, understanding the effects of dosage parameters, such as water content and $\mathrm{MgO}$ / $\mathrm{NH}_{4} \mathrm{H}_{2} \mathrm{PO}_{4}$ ratio on phase formation is essential for obtaining cementitious matrices with improved performance. In the present work $\mathrm{MgO}$ was sintered at $900{ }^{\circ} \mathrm{C}$ and $1110{ }^{\circ} \mathrm{C}$ in a conventional oven, and the effect of water concentration and $\mathrm{MgO} / \mathrm{NH}_{4} \mathrm{H}_{2} \mathrm{PO}_{4}$ (or ADP) ratio on the properties of MPC was evaluated in terms of phase formation by $\mathrm{X}$-ray diffraction, pore size distribution, mechanical properties, and microstructure. For less-reactive $\mathrm{MgO}$ (calcined at $1100^{\circ} \mathrm{C}$ ) with a high $\mathrm{MgO} / \mathrm{ADP}$ ratio, increased water content did not cause additional solubilization of ADP or formation of more hydrated phases, although the cement porosity increased. Compositions with more reactive $\mathrm{MgO}$ (calcined up to $900{ }^{\circ} \mathrm{C}$ ) formed dittmarite $\left(\mathrm{NH}_{4} \mathrm{MgPO}_{4} \cdot \mathrm{H}_{2} \mathrm{O}\right)$ independent of water content. Higher water content and $\mathrm{MgO}$ calcination temperature were associated with increased MPC setting time and decreased mechanical strength due to higher porosity.
\end{abstract}

Keywords: magnesium phosphate cements, sintering, water content, microstructure, properties.

\section{Introduction}

Sintering of ceramic materials is an important research topic, although this process entails significant energy consumption and cost when implemented at a large scale. The energy demand and the resource consumption are some of the environmental issues that have generated a major interest in the modern society ${ }^{1,2}$. Chemically bonded materials, such as ordinary Portland cement (OPC), can be used as an alternative to sintering ceramic materials. Formed by hydraulic chemical reactions, this material acquires mechanical resistance at ambient temperature, is low in cost, and is useful for applications that consume significant material.

However, there is a gap between the properties of $\mathrm{OPC}$ and those of sintered ceramics ${ }^{3}$. The use of reactive magnesium oxide $(\mathrm{MgO})$ as a cement binder can provide some advantages over $\mathrm{OPC}$ due to its lower calcination temperatures $\left(700^{\circ} \mathrm{C} \text { to } 1000^{\circ} \mathrm{C} \text { vs. } 1450{ }^{\circ} \mathrm{C}\right)^{4,5}$. Although sintered ceramics are more expensive than OPC, these ceramics have superior mechanical properties and are much more stable in acidic atmospheres or at elevated temperatures. Unfortunately, not all applications are entirely satisfied by either class of materials, indicating a need for other materials with intermediate properties such as chemically bonded phosphate ceramics (CBPCs), to fill this gap ${ }^{6}$.

CBPCs are formed by reactions between acid phosphate (such as potassium, ammonium, or aluminum) and metal

*e-mail: verasribeiro@hotmail.com oxide (such as magnesium, calcium, and zinc). These reactions form phosphoric bonds, as first discovered in the first half of the $20^{\text {th }}$ century with the emergence of dental cements (zinc phosphates). According to MA et al. ${ }^{2}$, two types of MPCs are used in engineering practice and academic research; one of them uses ammonium dihydrogen phosphate (ADP), whereas the other uses potassium dihydrogen phosphate (KDP) as the phosphate component.

The refractory industry has used this knowledge to develop chemically bonded refractories, either at room temperature, or thermally induced at low temperatures ${ }^{7}$. Kingery ${ }^{8}$ analyzed the reactions of various inorganic oxides with a phosphoric acid solution. These studies concluded that amphoteric, or slightly basic cations with small ionic radii, are the most effective options for the formation of chemically bonded ceramics. These studies described the phosphoric chemical bond as having an essential inorganic character that could be achieved by the following three mechanisms: chemical reaction of a siliceous material with phosphoric acid, chemical reaction of a metal oxide with phosphoric acid, and direct addition ("in situ") or formation of acid phosphates.

Sugama and Kukacka ${ }^{9}$ and Sugama ${ }^{10}$ developed cements consisting of magnesium and ammonium phosphate, as well as calcium aluminate, both utilized for the rapid repair of damaged structures. More recently, researchers have developed magnesium and potassium phosphate cements that are used for the treatment of hazardous solid waste ${ }^{6,11}$. 
The raw materials are mixed at an ambient temperature, and exothermic reactions immediately produce the ammonium and magnesium phosphate phases. These phases are hydrated and insoluble in water.

The main product of these reactions is a crystalline phase called struvite $\left(\mathrm{NH}_{4} \mathrm{MgPO}_{4} \cdot 6 \mathrm{H}_{2} \mathrm{O}\right)$, formed according to Equation 1 as follows:

$$
\mathrm{MgO}(\mathrm{s})+\mathrm{NH}_{4} \mathrm{H}_{2} \mathrm{PO}_{4}(\mathrm{~s})+5 \mathrm{H}_{2} \mathrm{O}(\mathrm{l}) \rightarrow \mathrm{MgNH}_{4} \mathrm{PO}_{4} \cdot 6 \mathrm{H}_{2} \mathrm{O}(\mathrm{s})
$$

Other phases, such as dittmarite $\left(\mathrm{NH}_{4} \mathrm{MgPO}_{4} \cdot \mathrm{H}_{2} \mathrm{O}\right)$, stercorite $\left[\mathrm{Na}\left(\mathrm{NH}_{4}\right) \mathrm{HPO}_{4} \cdot 4 \mathrm{H}_{2} \mathrm{O}\right]$ and schertelite $\left[\left(\mathrm{NH}_{4}\right)_{2} \mathrm{MgH}_{2}\left(\mathrm{PO}_{4}\right)_{2} \cdot 4 \mathrm{H}_{2} \mathrm{O}\right]$ are ordinarily observed during the hydration reaction; whereas hanaite $\left[\left(\mathrm{NH}_{4}\right)_{2} \mathrm{Mg}_{3}\left(\mathrm{HPO}_{4}\right)_{4} \cdot 8 \mathrm{H}_{2} \mathrm{O}\right]$, newberyite $\left[\mathrm{MgHPO}_{4} \cdot 3 \mathrm{H}_{2} \mathrm{O}\right]$, and other phosphate hydrates are found less frequently ${ }^{12}$.

Struvite $\left(\mathrm{NH}_{4} \mathrm{MgPO}_{4} \cdot 6 \mathrm{H}_{2} \mathrm{O}\right)$ is thermally stable in air, although this phase loses the $\mathrm{H}_{2} \mathrm{O}$ and $\mathrm{NH}_{3}$ molecules from its structure and decomposes at a temperature of $55^{\circ} \mathrm{C}$, forming an amorphous phase chemically represented by $\mathrm{MgHPO}_{4}$. This phase can be rehydrated in the presence of water and an ambient temperature, forming the original phase (struvite) and other amorphous and/or crystalline phases $^{13}$.

According to Abdelrazig and El-Jazairi ${ }^{13}$, the amount of principal reactants has a significant influence on the crystalline phases that are to be formed following the reaction; these phases are directly related to the mechanical resistance to the compression of cement. The amount of the principal reactants also influences the physical characteristics of the material, such as porosity and bulk density.

Considering the volume of water added to the mixture, cements with higher water/cement (w/c) ratios have larger pore volumes, and lower compressive strengths ${ }^{14,15}$, in agreement with the Griffith Law. Abdelrazig and El-Jazairi ${ }^{14}$ also observed changes in the geometry of struvite $\left(\mathrm{NH}_{4} \mathrm{MgPO}_{4} \cdot 6 \mathrm{H}_{2} \mathrm{O}\right)$ crystals with increasing amounts of water, specifically the formation of needles followed by tabular plates. The formation of needles during crystallization is known to provide adequate mechanical properties.

Ammonium dihydrogen phosphate $\left(\mathrm{NH}_{4} \mathrm{H}_{2} \mathrm{PO}_{4}\right)$, or ADP, reacts with magnesium oxide in the presence of water in an acid-base reaction. Recent studies ${ }^{16,17}$ report that the amount of hydrates decrease with an increasing amount of $\mathrm{NH}_{4} \mathrm{H}_{2} \mathrm{PO}_{4}$ : therefore, the strength of the magnesium phosphate cement (MPC) theoretically decreases. The strength of the $\mathrm{MgO}$ grains is significantly larger than that of the phosphate hydrates. Therefore, the lower the amount of ADP, the higher the strength of the MPC paste; given there is a sufficient amount of phosphate hydrates surrounding the $\mathrm{MgO}$ grains thoroughly ${ }^{16,17}$.

$\mathrm{Xu}$ et al. ${ }^{18}$ studied the reaction mechanism of the magnesium potassium phosphate cement (MKC) with a high magnesium-to-phosphate ratio and observed that this high $\mathrm{Mg} / \mathrm{PO}_{4}$ molar ratio suppresses the formation of potassium-free magnesium phosphate hydrates and that $\mathrm{K}$-struvite is possibly formed mainly with more phosphate than the theoretical value. Furthermore, the water/solid (w/s) ratio plays a crucial role on governing the reaction path of MKP cements. MA et al. ${ }^{2}$ observed when the water content is kept constant, at a magnesium-to-phosphate value equivalent to 6 , the cement consists of the lowest porosity and smallest critical pore diameter, and the highest compressive strength and lowest intrinsic permeability.

Recent studies have evaluated the effect of boric acid $\left(\mathrm{H}_{3} \mathrm{BO}_{3}\right)$ content $^{19}, \mathrm{MgO} / \mathrm{ADP}$ ratio $^{20}$, and microwave calcination of $\mathrm{MgO}^{21,22}$ on the properties and durability ${ }^{23}$ of MPCs. Therefore, since a consolidated dosage method for MPCs has not been reported yet, this study aims to evaluate the influence of water content and $\mathrm{MgO} / \mathrm{ADP}$ ratio on the properties of MPC using MgO calcined at different temperatures, formation reactions (setting time and phases formed), microstructure, porosity, and mechanical strength of these materials.

\section{Materials and Methods}

\subsection{Materials}

The materials used were raw materials with commercial purity, although raw materials with a high purity were used when necessary to assist in the analysis of phase formation. The primary materials used were $\mathrm{MgO}, \mathrm{ADP}\left(\mathrm{NH}_{4} \mathrm{H}_{2} \mathrm{PO}_{4}\right)$, and $\mathrm{H}_{3} \mathrm{BO}_{3}$ (setting time retarder).

\subsubsection{Magnesium oxide}

$\mathrm{MgO}$ (basic component) needed to be calcined due to its high surface area. $\mathrm{MgO}$ was calcined using a Termolab BL 260/03 oven, with a heating rate of $10^{\circ} \mathrm{C} / \mathrm{min}$.

Rezaei et al. ${ }^{24}$ calcined $\mathrm{MgO}$ at $700^{\circ} \mathrm{C}$ for $2 \mathrm{~h}$, yielding unsatisfactory results. Sonat el $\mathrm{al}^{25}$. calcined the $\mathrm{MgO}$ at temperatures between $700{ }^{\circ} \mathrm{C}$ and $1100{ }^{\circ} \mathrm{C}$, and found that the calcination temperature had a significant effect on the strength values for shorter residence times $(2 \mathrm{~h})$, whereas the strength of samples subjected to $6 \mathrm{~h}$ of calcination did not change significantly between the temperature range of $700{ }^{\circ} \mathrm{C}$ to $900{ }^{\circ} \mathrm{C}$. In this study, two distinct temperatures of $900{ }^{\circ} \mathrm{C}$ and $1100{ }^{\circ} \mathrm{C}$ were selected, and the dwell time was fixed to $2 \mathrm{~h}$.

The original $\mathrm{MgO}$ provided by Buschle \& Lepper S.A. had a specific surface area of $46.02 \mathrm{~m}^{2} / \mathrm{g}$, unitary mass of $1.34 \mathrm{~kg} / \mathrm{dm}^{3}$, and specific gravity of $2.79 \mathrm{~kg} / \mathrm{dm}^{3}$.

\subsubsection{Ammonium dihydrogen phosphate}

Ammonium dihydrogen phosphate $\left(\mathrm{NH}_{4} \mathrm{H}_{2} \mathrm{PO}_{4}\right)$, or ADP, reacts with $\mathrm{MgO}$ in the presence of water in an acid-base reaction. The ADP used, provided by LabSynth, had a surface area of $0.68 \mathrm{~m}^{2} / \mathrm{g}$, unitary mass of $0.79 \mathrm{~kg} / \mathrm{dm}^{3}$, and specific gravity of $1.87 \mathrm{~kg} / \mathrm{dm}^{3}$.

\subsubsection{Boric acid}

Retardants increased the setting time and decreased the intensity of the exothermic reaction during the initial setting and hardening stage by delaying the setting time of reactions, improving the working conditions, and providing the necessary time required for the reactions to complete, thereby effectively forming phosphates ${ }^{26}$. Therefore, chemical retardants are utilized in large-scale mixing operations. Commercial $\mathrm{H}_{3} \mathrm{BO}_{3}$ (provide by LabSynth) containing approximately $98 \% \mathrm{H}_{3} \mathrm{BO}_{3}$ was used. 


\subsection{Methods}

\subsubsection{Material characterization}

The materials were characterized by X-ray diffractometry (XRD) (Rigaku Geigerflex ME 210GF2 Diffractometer, configured with $\mathrm{CuK} \alpha$ radiation, $40 \mathrm{kV}$ of voltage, $100 \mathrm{~mA}$ of current, $10^{\circ}-80^{\circ} 2 \theta$ scanning, and $4 \%$ min of scanning speed), X-ray fluorescence (XRF - Philips PW1480 X-ray Fluorescence Spectrometer), Fourier transform infrared spectroscopy (Bruker Tensor 27 FTIR spectrometer, wavenumber range of 4000 to $450 \mathrm{~cm}^{-1}$ ), and scanning electron microscopy (Philips SEM, model XL 30 FEG, gold coating) to evaluate the phase and chemical compositions. Before performing XRD, XRF and FTIR tests, the samples were ground to a grain size of less than $75 \mu \mathrm{m}$.

Relevant physical parameters such as the particle size distribution (Horiba sedentary model CP5000), mercury porosimetry (Porosizer 9320, Micromeritics), specific surface area estimated by BET (using a Micrometrics Gemini 2370 V1.02 equipment), and specific gravity (Helium Pycnometer Accupyc 1330 V2.01 from Micrometrics) were determined.

\subsubsection{Dosage and molding of specimens}

Two cement compositions were prepared following the calcination of $\mathrm{MgO}$. Each of these compositions had different mass proportions of $\mathrm{MgO} / \mathrm{NH}_{4} \mathrm{H}_{2} \mathrm{PO}_{4}$ and water contents ( $40 \%$ to $80 \%)$, as shown in Table 1 .

The amount of retardant $\left(\mathrm{H}_{3} \mathrm{BO}_{3}\right)$ added was $15 \%$ of the total mass of $\mathrm{MgO}$, based on the studies of Yang and $\mathrm{Wu}^{27}$. Since these compositions had different concentrations of $\mathrm{MgO}$, the amount of retardant varied for each composition.

Test specimens were molded by mixing three base materials, i.e., $\mathrm{MgO}, \mathrm{NH}_{4} \mathrm{H}_{2} \mathrm{PO}_{4}$, and $\mathrm{H}_{3} \mathrm{BO}_{3}$, in different proportions with water at room temperature for $1 \mathrm{~min}$. From this mixture, cubic specimens with dimensions of $3 \times 3 \times 3 \mathrm{~cm}^{3}$ were molded using a vibratory table, except for the specimens used for the measurement of mechanical strength, which were molded into cylindrical molds $(\varphi 25 \mathrm{~mm} \times 50 \mathrm{~mm})$. The cubic specimens were used to extract pieces and evaluate the phases formation (XRD, FTIR), the morphology (SEM) and pore size distribution (MIP) of MPC compositions.

\subsubsection{Composition characterization}

To characterize the compositions, indirect measurements of the setting time were performed as proposed by Hall and Stevens ${ }^{26}$. In addition, the compositions were characterized by X-ray diffractometry (XRD), FTIR, scanning electron microscopy (SEM), mechanical strength testing, and mercury intrusion porosimetry (MIP).

According to the Brazilian standard NBR NM 65:2003 ("Portland Cement - Determination of Setting Time), measurement of the setting time should be performed using the Vicat apparatus. However, recent studies ${ }^{3,11,19-23,26,28-30}$ have shown that the setting time for magnesium phosphate cements can be indirectly determined by calorimetry assays. These authors observed a direct relationship between the results obtained by calorimetric measurements and using the Vicat apparatus. Since the formation of the hydrated phases in cements is an exothermic reaction, the temperature measurements during hardening results in indirect data that can provide comparative values of setting time. In this study, a Raytec MT infrared pyrometer was used to perform such measurements at random time intervals until a reduction in the mixture temperature could be verified.

The phases of the cement were identified by XRD in experiments using the Rigaku Geigerflex ME 210GF2 diffractometer, copper targets of $40 \mathrm{kV}$ and $40 \mathrm{~mA}$, and a monochromatic graphite filter system. A diffraction spectrum was obtained in the range of $2 \theta 5^{\circ}-75^{\circ}$ at $2^{\circ} / \mathrm{min}$. The phases in the samples were identified using the DIFFRAC plus-EVA software; its database follows the Joint Committee on Power Diffraction Standards (JCPDS) system.

The values of axial compression correspond to the average of 5 values for each magnesium phosphate composition that was obtained 28 days after molding, using an Instron 5500R universal testing machine, and a displacement rate of $1.5 \mathrm{~mm} / \mathrm{min}$. Values that differed by more than $5 \%$ from the average were not considered, and substituted for the results of new samples.

Table 1. Compositions used to evaluate the effect of the water and $\mathrm{ADP}\left(\mathrm{NH}_{4} \mathrm{H}_{2} \mathrm{PO}_{4}\right)$ contents in magnesium phosphate cement compositions.

\begin{tabular}{|c|c|c|c|c|c|}
\hline Composition* & $\begin{array}{c}\mathrm{MgO} \\
(\%, \text { in mass })\end{array}$ & $\begin{array}{c}\text { ADP } \\
(\%, \text { in mass })\end{array}$ & $\begin{array}{c}\mathrm{MgO} / \mathrm{ADP} \\
\text { Ratio }\end{array}$ & $\begin{array}{c}\mathrm{H}_{2} \mathrm{O} \\
(\%, \text { in mass })^{* *}\end{array}$ & $\begin{array}{c}\text { Boric } \\
\text { Acid (\%) }{ }^{* * *}\end{array}$ \\
\hline C_01 - $40 \% \mathrm{H}_{2} \mathrm{O}$ & \multirow{5}{*}{70} & \multirow{5}{*}{30} & \multirow{5}{*}{2.33} & 40 & \multirow{5}{*}{15} \\
\hline C_01 $-50 \% \mathrm{H}_{2} \mathrm{O}$ & & & & 50 & \\
\hline C_ $01-60 \% \mathrm{H}_{2} \mathrm{O}$ & & & & 60 & \\
\hline C_ $01-70 \% \mathrm{H}_{2} \mathrm{O}$ & & & & 70 & \\
\hline C_ $01-80 \% \mathrm{H}_{2} \mathrm{O}$ & & & & 80 & \\
\hline C_04 $-40 \% \mathrm{H}_{2} \mathrm{O}$ & \multirow{5}{*}{55} & \multirow{5}{*}{45} & \multirow{5}{*}{1.22} & 40 & \multirow{5}{*}{15} \\
\hline C_04-50\% $\mathrm{H}_{2} \mathrm{O}$ & & & & 50 & \\
\hline C_ $04-60 \% \mathrm{H}_{2} \mathrm{O}$ & & & & 60 & \\
\hline C_04 - $70 \% \mathrm{H}_{2} \mathrm{O}$ & & & & 70 & \\
\hline C_04 $-80 \% \mathrm{H}_{2} \mathrm{O}$ & & & & 80 & \\
\hline
\end{tabular}

* Stoichiometric composition for the formation of $100 \%$ struvite $\left(\mathrm{NH}_{4} \mathrm{MgPO}_{4} \cdot 6 \mathrm{H}_{2} \mathrm{O}\right)$ is composed by $26 \%$ and $74 \% \mathrm{ADP}$, in mass. ** \% relative to the mass of $\mathrm{MgO}+\mathrm{NH}_{4} \mathrm{H}_{2} \mathrm{PO}_{4} \cdot{ }^{* * *} \%$ in relation to the mass of $\mathrm{MgO}$ (calcined at $900{ }^{\circ} \mathrm{C} / 2 \mathrm{~h}$ and $1100{ }^{\circ} \mathrm{C} / 2 \mathrm{~h}$ ). 


\section{Results and Discussion}

\subsection{Material characterization}

The chemical compositions of $\mathrm{MgO}, \mathrm{ADP}$, and $\mathrm{H}_{3} \mathrm{BO}_{3}$ are shown in Table 2.

The chemical purity of $\mathrm{MgO}$ provided by the manufacturer was $96.28 \%$, which was close to the experimental value, $97.26 \%$. The significant loss on ignition (LOI) could be indicative of both, the high concentration of $\mathrm{MgO}$ in the

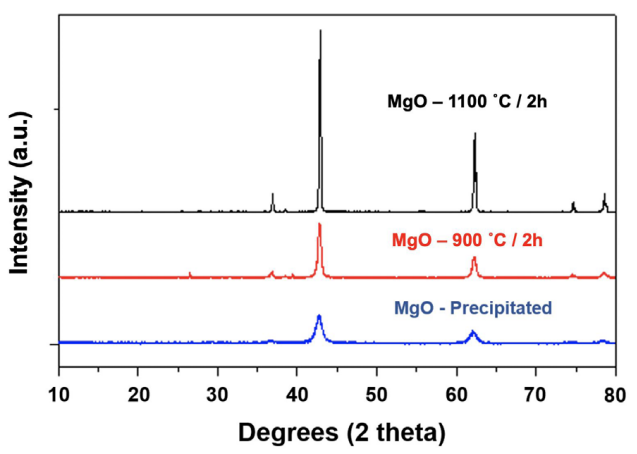

Figure 1. X-ray diffractograms of $\mathrm{MgO}$ powders in two conditions: precipitated and after calcination at different temperatures $\left(900{ }^{\circ} \mathrm{C}\right.$ and $1100{ }^{\circ} \mathrm{C}$, for $2 \mathrm{~h}$ ). form of $\mathrm{MgCO}_{3}$ or $\mathrm{Mg}(\mathrm{OH})_{2}$, as well as the large amount of water adsorbed on the $\mathrm{MgO}$ particles.

Figure 1 shows the X-ray diffractograms of $\mathrm{MgO}$ powders in two conditions: precipitated, and after different calcination temperatures $\left(900^{\circ} \mathrm{C}\right.$ and $1100{ }^{\circ} \mathrm{C}$, for $2 \mathrm{~h}$ ).

Figure 1 shows that as the calcination temperature is increased, the diffraction peaks have smaller widths and larger intensities. According to Kingery and Francois ${ }^{31}$, this observation is directly related to the average crystallite size of the particles of the powder in question. Thus, the calcined powder at $1100^{\circ} \mathrm{C} / 2 \mathrm{~h}$ had a larger crystallite size and greater crystallinity than others. Furthermore, no secondary phases such as magnesium carbonates or hydroxides were present in these diffractograms; they may be present at levels below the equipment detection capacity, or in less crystalline forms. Thus, significant LOI in these $\mathrm{MgO}$ powders was associated with the presence of large amounts of adsorbed water on the particles in the powders.

Figure 2 shows the morphology obtained by SEM for the investigated $\mathrm{MgO}$ powders. As expected, higher calcination temperatures led to an increase in the mean particle size. Unlike calcined powders, which have well defined spherical surfaces, powders without calcination (precipitates) present irregular surfaces. This irregularity and relatively small size is responsible for the high surface area and adsorption of large amounts of water on the surface of these powders.
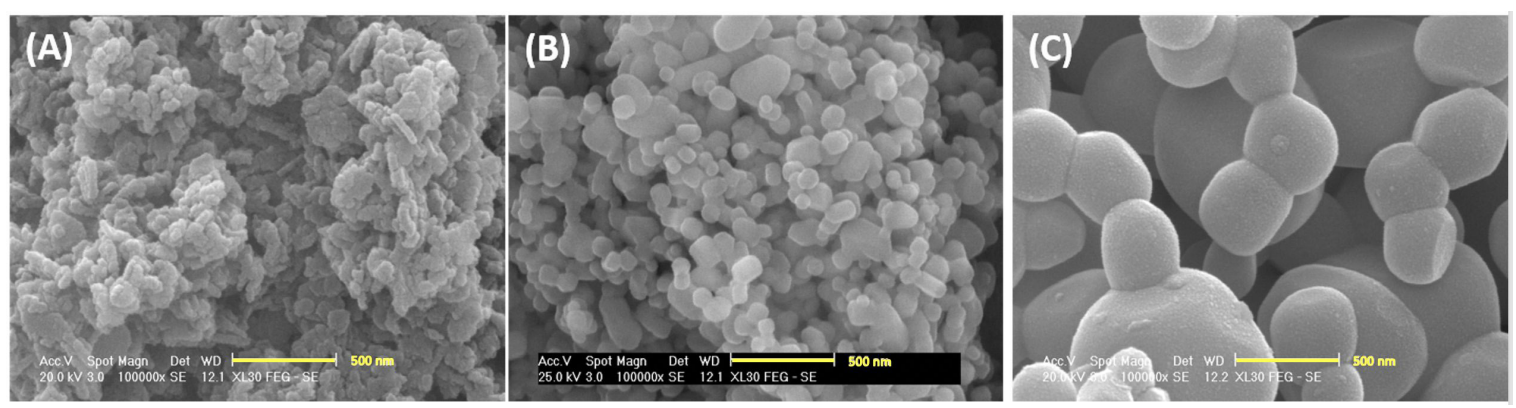

Figure 2. Morphology obtained by SEM of $\mathrm{MgO}(\mathrm{A})$ without calcination, (B) calcined at $900{ }^{\circ} \mathrm{C}$ for $2 \mathrm{~h}$, and (C) calcined at $1100{ }^{\circ} \mathrm{C}$ for $2 \mathrm{~h}$.

Table 2. Chemical compositions of magnesium oxide $(\mathrm{MgO})$, ammonium dihydrogen monophosphate $\left(\mathrm{NH}_{4} \mathrm{H}_{2} \mathrm{PO}_{4}, \mathrm{ADP}\right)$ and boric acid $\left(\mathrm{H}_{3} \mathrm{BO}_{3}\right)$, estimated by XRF (oxides).

\begin{tabular}{cccc}
\hline \multirow{2}{*}{ Component (Oxide) } & & Material & $\mathrm{H}_{3} \mathrm{BO}_{3}$ \\
\cline { 2 - 4 } & $\mathrm{MgO}$ & $\mathrm{ADP}$ & --- \\
\hline $\mathrm{MgO}(\%)$ & 78.19 & --- & --- \\
\hline $\mathrm{SiO}_{2}(\%)$ & 0.52 & --- & -- \\
\hline $\mathrm{Fe}_{2} \mathrm{O}_{3}(\%)$ & 0.13 & --- & --- \\
\hline $\mathrm{CaO}(\%)$ & 1.18 & --- & --- \\
\hline $\mathrm{Al}_{2} \mathrm{O}_{3}(\%)$ & 0.30 & --- & --- \\
\hline $\mathrm{MnO}(\%)$ & 0.02 & --- & --- \\
\hline $\mathrm{P}_{2} \mathrm{O}_{5}(\%)$ & 0.02 & 60.67 & --- \\
\hline $\mathrm{Na}_{2} \mathrm{O}(\%)$ & $<0.01$ & --- & -- \\
\hline $\mathrm{K}_{2} \mathrm{O}(\%)$ & -0.01 & --- \\
\hline $\mathrm{TiO}_{2}(\%)$ & 0.04 & --- & 56.4 \\
\hline $\mathrm{B}_{2} \mathrm{O}_{3}(\%)$ & -- & --- & \\
\hline $\mathrm{LOI}^{\mathrm{a}}(\%)$ & 19.61 & & - \\
\hline
\end{tabular}

${ }^{\mathrm{a}} \mathrm{LOI}=$ loss on ignition 
Figure 3 shows the particle size distribution of the tested $\mathrm{MgO}$ powders. These results are in agreement with the expected results; an increase in the mean particle size due to a higher calcination temperature was observed, according to Figure 2. However, by comparing Figures 2 and 3, the agglomerates present in these powders were not adequately dispersed (Figure 2A) despite the powders being passed through a 200-mesh screen followed by the subjection to ultrasonic dispersion for three minutes. As shown in Figures $2 \mathrm{~B}$ and $2 \mathrm{C}$, it is possible to observe the aggregated particles as a consequence of the sintering process. This result occurred because the average particle size in Figure 2 was much lower than that observed in Figure 3, especially for precipitated powders and those calcined at $900^{\circ} \mathrm{C}$.

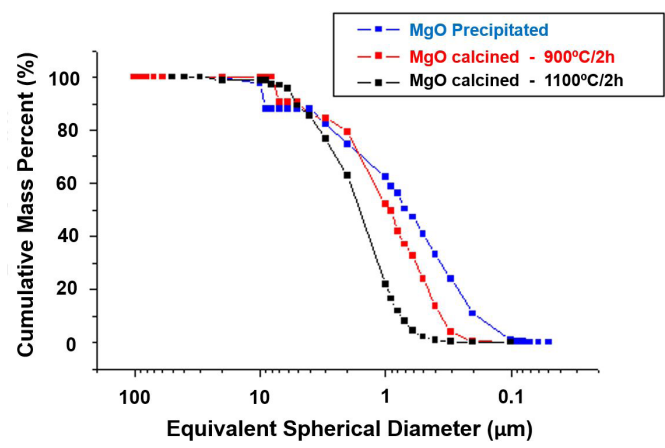

Figure 3. Particle size distribution of precipitated (non-calcined) $\mathrm{MgO}$ powders and those calcined at $900{ }^{\circ} \mathrm{C}$ and $1100^{\circ} \mathrm{C}$ for $2 \mathrm{~h}$.
The precipitated powder (without calcination) and $\mathrm{MgO}$ sample calcined at $900{ }^{\circ} \mathrm{C} / 2 \mathrm{~h}$ and $1100{ }^{\circ} \mathrm{C} / 2 \mathrm{~h}$ had a bimodal and monomodal particle size distribution, respectively. This occurred due to the high surface area of the precipitated powders for powders calcined at $900{ }^{\circ} \mathrm{C} / 2 \mathrm{~h}$, which easily formed a few large agglomerates in addition to the existing aggregates. For powders calcined at $1100^{\circ} \mathrm{C} / 2 \mathrm{~h}$, the monomodal particle size distribution probably represented hard agglomerates (aggregates), resulting from presintering, as observed in the microscopic analysis (Figure 2C).

Table 3 shows the densities and specific surface areas of $\mathrm{MgO}$ powders precipitated and calcined at different temperatures.

There was a gradual increase in the density and decrease in the surface area of calcined $\mathrm{MgO}$ powders, as the calcination temperature increased with density approaching the theoretical value of $3.58 \mathrm{~g} / \mathrm{cm}^{324}$. It was also observed that an increase in the calcination temperature led to a decrease in the specific surface area values and consequently, high reactivity of noncalcined (precipitated) powders. A decrease in the surface area values with an increase in the calcination temperature was indicative of the increased average particle size and/or agglomeration, reducing its reactivity.

Thus, the $\mathrm{MgO}$ powder calcined at $1100^{\circ} \mathrm{C} / 2 \mathrm{~h}$ had lower solubility than that calcined at $900{ }^{\circ} \mathrm{C} / 2 \mathrm{~h}$, due to a higher average particle size (lower specific surface area) and crystallinity.

\subsection{Composition characterization}

Figure 4 shows the XRD results of compositions $\mathrm{C}_{-} 01$ and $\mathrm{C} \_04$ that were prepared from $\mathrm{MgO}$ powders calcined at $900{ }^{\circ} \mathrm{C} / 2 \mathrm{~h}$ and $1100{ }^{\circ} \mathrm{C} / 2 \mathrm{~h}$, respectively, using different water contents and $\mathrm{MgO} / \mathrm{ADP}$ ratios.
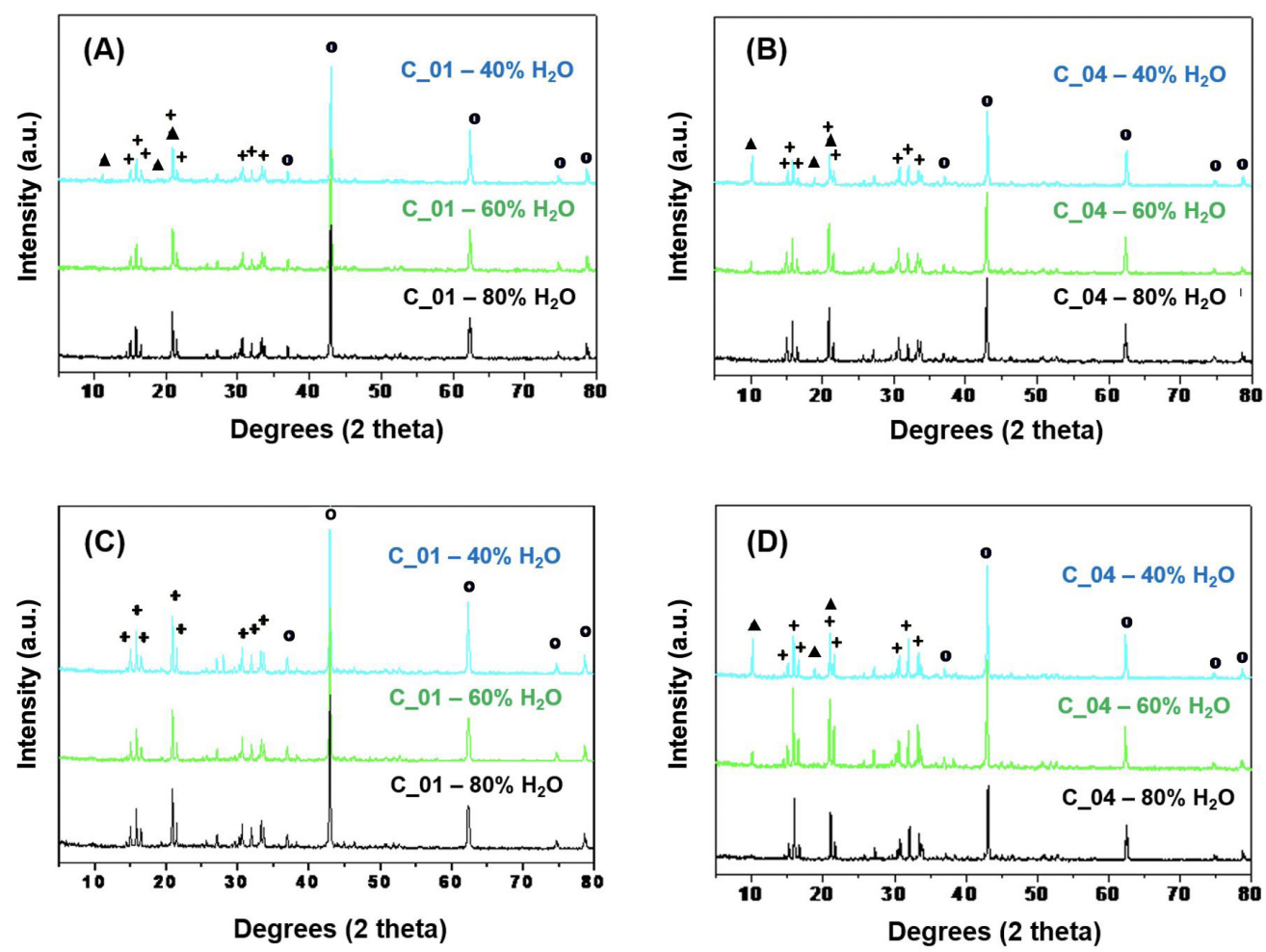

Figure 4. X-ray diffractograms of compositions C_ 01 and C_ 04 prepared from $\mathrm{MgO}$ powders calcined at (A and B) $900{ }^{\circ} \mathrm{C} / 2 \mathrm{~h}$ and (C and D) $1100{ }^{\circ} \mathrm{C} / 2 \mathrm{~h}$, respectively, with different water contents. (Phases: + struvite; $\boldsymbol{\Delta}$ dittmarite; $\circ \mathrm{MgO}$ ). 
Compositions C_01 and C_04 (Figures 4A and 4B) were prepared with $\mathrm{MgO}$ calcined at $900{ }^{\circ} \mathrm{C} / 2 \mathrm{~h}$ with different water contents, and had a tendency to form dittmarite $\left(\mathrm{NH}_{4} \mathrm{MgPO}_{4} \cdot \mathrm{H}_{2} \mathrm{O}\right)$, which was a result of the increased surface area of $\mathrm{MgO}$ calcined at $900^{\circ} \mathrm{C}$ than that calcined at $1100^{\circ} \mathrm{C}$. When water adsorbed on the surface of this oxide, the water concentration was insufficient for the complete formation of struvite $\left(\mathrm{NH}_{4} \mathrm{MgPO}_{4} \cdot 6 \mathrm{H}_{2} \mathrm{O}\right)$ due to the short setting time of these cements.

For the compositions containing $\mathrm{MgO}$ calcined at $1100^{\circ} \mathrm{C} / 2 \mathrm{~h}$ (Figures 4C and 4D), the water content did not modify the diffraction curves of composition C $01(70 \% \mathrm{MgO})$, in contrast to the modified curves of composition C_04 (55\% MgO). This behavior could be a consequence of excess water being available for the formation of hydrated phases when the concentration of $\mathrm{MgO}$ in the mixture was reduced. Composition C_01 had sufficient solubility due to the low amount of ADP present, even at low water concentrations of approximately $40 \%$; in this case, all the ADP would be quickly consumed for the formation of hydrated phases. Increasing the water content would not lead to additional solubilization of ADP, nor the formation of more hydrated phases. However, this case did increase the porosity of the cement.

For composition C_04, lower percentages of water were associated with higher concentrations of dittmarite $\left(\mathrm{NH}_{4} \mathrm{MgPO}_{4} \cdot \mathrm{H}_{2} \mathrm{O}\right)$. Figure 4 suggests that when small amounts of water are available, the formation of dittmarite is greater since this phase is formed initially, requiring only one water molecule in its composition $\left(\mathrm{NH}_{4} \mathrm{MgPO}_{4} \cdot \mathrm{H}_{2} \mathrm{O}\right)$. When more water is available, the struvite phase $\left(\mathrm{NH}_{4} \mathrm{MgPO}_{4} \cdot 6 \mathrm{H}_{2} \mathrm{O}\right)$, which is thermally more stable but needs more water for its formation, is present in a greater proportional quantity reducing the amount of the dittmarite phase.

If water was present at low concentrations and added to formulations with a high surface area of $\mathrm{MgO}$, there would be a lack of water for the total struvite formation. Under these conditions, dittmarite $\left(\mathrm{NH}_{4} \mathrm{MgPO}_{4} \cdot \mathrm{H}_{2} \mathrm{O}\right)$ formation would be the most prevalent phase since this phase has five fewer molecules of $\mathrm{H}_{2} \mathrm{O}$ than struvite $\left(\mathrm{NH}_{4} \mathrm{MgPO}_{4} \cdot 6 \mathrm{H}_{2} \mathrm{O}\right)$. Dittmarite $\left(\mathrm{NH}_{4} \mathrm{MgPO}_{4} \cdot \mathrm{H}_{2} \mathrm{O}\right)$ is the dominant phase when the reaction is fast, whereas struvite $\left(\mathrm{NH}_{4} \mathrm{MgPO}_{4} \cdot 6 \mathrm{H}_{2} \mathrm{O}\right)$ dominates when the reaction is slow ${ }^{32}$.

To confirm this hypothesis, Figure 5 shows the infrared (IR) spectra of the $\mathrm{C}_{0} 04$ compositions that were prepared with different water contents, and $\mathrm{MgO}$ calcined at $1100^{\circ} \mathrm{C}$.

Multiple peaks between 1400 and $1300 \mathrm{~cm}^{-1}$ ( $v_{2}$ of the $\mathrm{NH}_{4}^{+}$groups) are indicative of the strong presence of dittmarite $\left(\mathrm{NH}_{4} \mathrm{MgPO}_{4} \cdot \mathrm{H}_{2} \mathrm{O}\right)$ when the water content was $40 \%$. A decrease in the band intensity at 3650 and $1660 \mathrm{~cm}^{-1}$ is also observable, which correspond to the stretching vibrations of the $\mathrm{H}_{2} \mathrm{O}$ molecules $\left(v_{1}\right.$ e $\left.v_{3}\right)$. Figure 5 shows that an increased amount of water led to the preferential formation of struvite $\left(\mathrm{NH}_{4} \mathrm{MgPO}_{4} \cdot 6 \mathrm{H}_{2} \mathrm{O}\right)$ than dittmarite $\left(\mathrm{NH}_{4} \mathrm{MgPO}_{4} \cdot \mathrm{H}_{2} \mathrm{O}\right)$. All these peaks were observed increasingly with increased ADP amount in the cement, indicative of the formation of the hydrated phases. Such behavior is in agreement with the results observed in Figure 4.

Finally, in addition to the 590 and $510 \mathrm{~cm}^{-1}$ peaks associated with the angular deformation vibrations $v_{2}$ and $v_{4}$ of the same $\mathrm{PO}_{4}^{-3}$ groups, there is a strong band between
900 and $780 \mathrm{~cm}^{-1}$ due to the overlapping of the peaks related to the ammonia-water bonds (higher wavelength) for the deformation of the water molecules present in the structure.

Figure 6 shows the effect of the water content on the temperature evolution of compositions C_01 (70\% MgO) and C_04 (55\% MgO). For compositions containing $\mathrm{MgO}$ powders calcined at $900{ }^{\circ} \mathrm{C} / 2 \mathrm{~h}$ and $1100{ }^{\circ} \mathrm{C} / 2 \mathrm{~h}$, increasing the amount of added water led to increased setting time (retarding the peak temperature), independent of the composition.

The amount and temperature of the water used in the admixture are critical for the formation of MPC. From the viewpoint of setting time, higher water contents and lower temperatures of the water-phosphate solution lead to longer setting times for the magnesium phosphate cements. Lower temperatures of solution decrease the dissolution of the $\mathrm{MgO}$ grains, thereby retarding the setting time ${ }^{13,15}$.

An increase in temperature favors the occurrence of reactions that lead to the formation of hydrated phases, which is also associated with higher surface temperatures of the samples. The same behavior is true for the types of phases formed. Since dittmarite $\left(\mathrm{NH}_{4} \mathrm{MgPO}_{4} \cdot \mathrm{H}_{2} \mathrm{O}\right)$ has a greater standard enthalpy of formation than that of struvite $\left(\mathrm{NH}_{4} \mathrm{MgPO}_{4} \cdot 6 \mathrm{H}_{2} \mathrm{O}\right)$, the temperature on the surface of the cement should also increase $\mathrm{e}^{13,15}$

Composition C_01 did not show significant variations in the surface temperature of the cements, since it did not show the formation of dittmarite $\left(\mathrm{NH}_{4} \mathrm{MgPO}_{4} \cdot \mathrm{H}_{2} \mathrm{O}\right)$. This composition had low sensitivity to increasing amounts of water, and little variation in the concentration of its hydrated phases.

Schertelite $\left[\mathrm{Mg}\left(\mathrm{NH}_{4}\right)_{2}\left(\mathrm{HPO}_{4}\right)_{2} \cdot 4\left(\mathrm{H}_{2} \mathrm{O}\right)\right]$ is formed as a reaction intermediate and converts into struvite or

Table 3. Density and specific surface area of $\mathrm{MgO}$ powders precipitated and sinterized at different temperatures

\begin{tabular}{lcc}
\hline \multicolumn{1}{c}{ MgO Powder } & $\begin{array}{c}\text { Density } \\
\left(\mathrm{g} / \mathrm{cm}^{3}\right)\end{array}$ & $\begin{array}{c}\text { Specific Surface } \\
\text { Area BET }\left(\mathrm{m}^{2} / \mathrm{g}\right)\end{array}$ \\
\hline $\begin{array}{l}\text { Precipitated } \\
\text { (without sinterization) }\end{array}$ & 2.79 & 46.02 \\
\hline Sinterized at $900^{\circ} \mathrm{C} / 2 \mathrm{~h}$ & 3.34 & 24.68 \\
\hline Sinterized at $1100{ }^{\circ} \mathrm{C} / 2 \mathrm{~h}$ & 3.53 & 7.87 \\
\hline
\end{tabular}

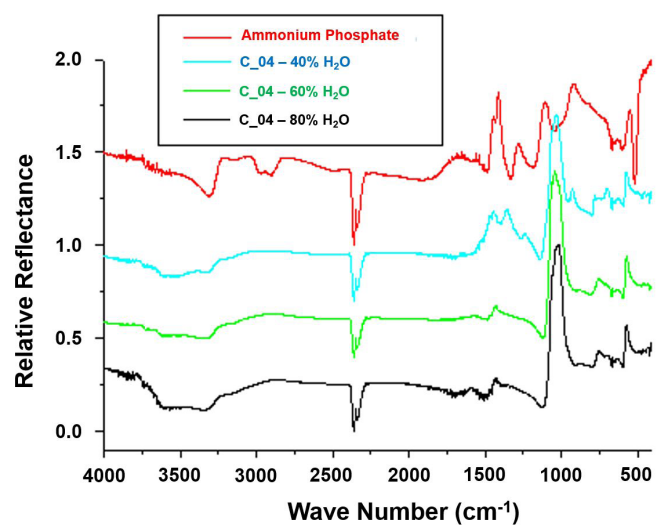

Figure 5. FTIR spectra of magnesium phosphate cements with different water contents, containing $\mathrm{MgO}$ powders calcined at $1100^{\circ} \mathrm{C}$. 


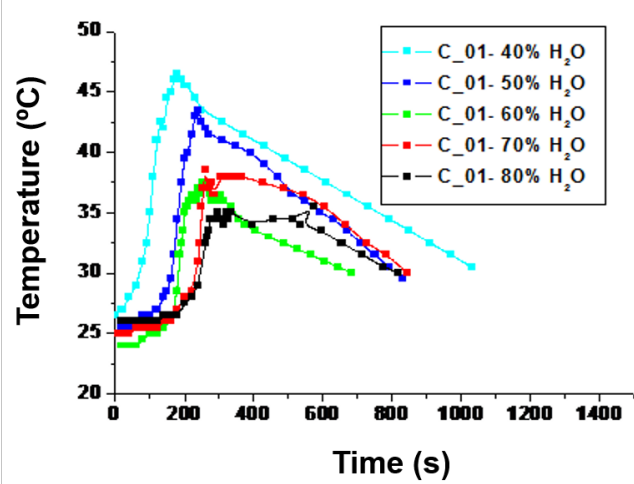

(A)

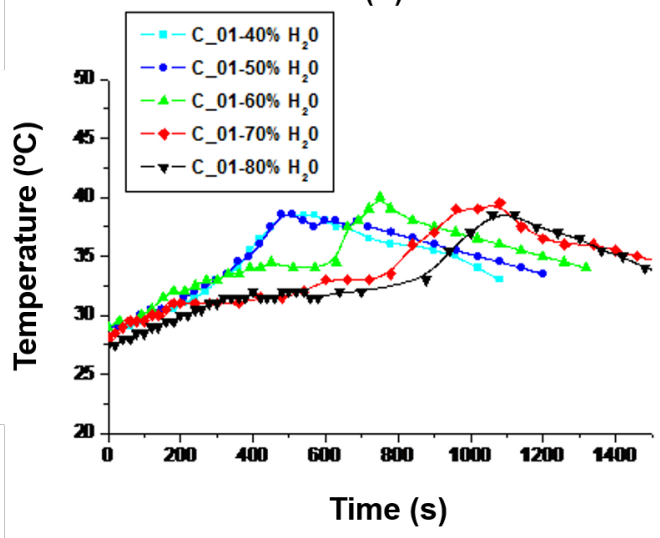

(C)

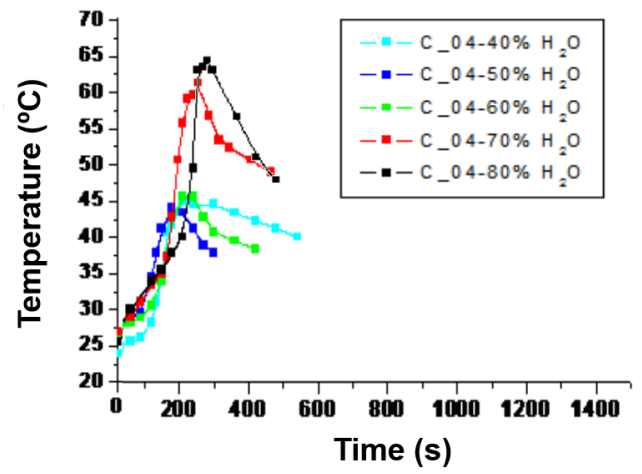

(B)

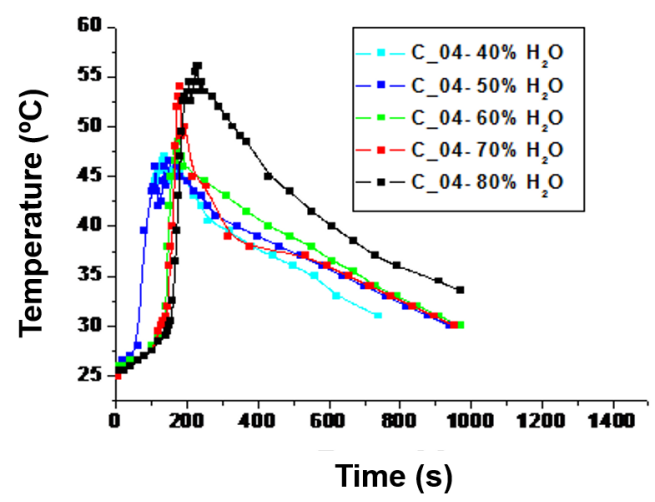

(D)

Figure 6. Effect of water content on the temperature evolution of compositions containing $\mathrm{MgO}$ powders calcined at $900{ }^{\circ} \mathrm{C} / 2 \mathrm{~h}$ (A) and (B) and at $1100{ }^{\circ} \mathrm{C} / 2 \mathrm{~h}(\mathrm{C})$ and (D).

dittmarite ${ }^{11,28,29}$, according to the reactions (2) and (3). Struvite $\left(\mathrm{NH}_{4} \mathrm{MgPO}_{4} \cdot 6 \mathrm{H}_{2} \mathrm{O}\right)$ and dittmarite $\left(\mathrm{NH}_{4} \mathrm{MgPO}_{4} \cdot \mathrm{H}_{2} \mathrm{O}\right)$ are chemically and structurally similar, and the transformation from one to the other does not cause any microstructural damage to the molded specimen. Thus, a higher amount of water leads to the formation of struvite (Equation 3), delaying the setting time and resulting in a matrix with less free $\mathrm{MgO}$.

$$
\mathrm{MgO}+\mathrm{NH}_{4} \mathrm{H}_{2} \mathrm{PO}_{4}+3 \mathrm{H}_{2} \mathrm{O} \rightarrow \mathrm{Mg}\left(\mathrm{NH}_{4}\right)_{2}\left(\mathrm{HPO}_{4}\right)_{2} \cdot 4\left(\mathrm{H}_{2} \mathrm{O}\right)
$$

$\mathrm{Mg}\left(\mathrm{NH}_{4}\right)_{2}\left(\mathrm{HPO}_{4}\right)_{2} \cdot 4\left(\mathrm{H}_{2} \mathrm{O}\right)+\mathrm{MgO}+7 \mathrm{H}_{2} \mathrm{O} \rightarrow \mathrm{MgNH}_{4} \mathrm{PO}_{4} \cdot 6 \mathrm{H}_{2} \mathrm{O}$

Additionally, C_01 had a longer setting time represented by a delay in time at the peak temperature ${ }^{9,10,18,22}$ than C_04 for the same water content when $\mathrm{MgO}$ powders calcined at $1100^{\circ} \mathrm{C} / 2 \mathrm{~h}$ were used; however, this behavior is insignificant when using $\mathrm{MgO}$ powders calcined at $900^{\circ} \mathrm{C} / 2 \mathrm{~h}$. The longer setting time for the $\mathrm{C}_{-} 01$ composition is associated with the higher $\mathrm{MgO} / \mathrm{NH}_{4} \mathrm{H}_{2} \mathrm{PO}_{4}$ ratio, leading to the formation of a greater amount of struvite $\left(\mathrm{NH}_{4} \mathrm{MgPO}_{4} \cdot 6 \mathrm{H}_{2} \mathrm{O}\right)$. $\mathrm{MgO}$ calcined at $900{ }^{\circ} \mathrm{C} / 2 \mathrm{~h}$ did not present the same behavior. Due to its high reactivity, reactions occur intensely, even with a higher $\mathrm{MgO} / \mathrm{NH}_{4} \mathrm{H}_{2} \mathrm{PO}_{4}$ ratio.

The water content exerts an important influence on the microstructure, as well as the physical and mechanical properties of the magnesium phosphate cements. Figure 7 shows the effect of water addition on the pore size distribution of these samples.

As expected, as the amount of water increased, the samples became more porous and had a larger pore size. Thus, when using $\mathrm{MgO}$ powders calcined at $900^{\circ} \mathrm{C} / 2 \mathrm{~h}$ and $1100^{\circ} \mathrm{C} / 2 \mathrm{~h}$, the cements of the $\mathrm{C} 04$ composition had a lower open pore volume than those of the $\mathrm{C} 01$ composition. As discussed previously, the C_04 composition used a greater amount of water to form the hydrated phases than $\mathrm{C}_{-} 01$ composition (higher $\mathrm{MgO} / \mathrm{NH}_{4} \mathrm{H}_{2} \mathrm{PO}_{4}$ ratio), allowing the free water to evaporate and form pores in the material.

The microstructures of the compositions are shown in Figures 8 and 9. Regardless of the composition and calcination temperature of $\mathrm{MgO}$, cements prepared with higher water contents formed struvite $\left(\mathrm{NH}_{4} \mathrm{MgPO}_{4} \cdot 6 \mathrm{H}_{2} \mathrm{O}\right)$ crystals with a smaller average size. Although there were no significant changes in the concentration of the hydrated phases for C_ 01 , an increase in the water volume resulted in a decrease the size and mean diameter of the struvite crystals.

According to several studies ${ }^{12,28-30}$, the mechanism of phase formation in magnesium phosphate cements occurs by the solubilization of $\mathrm{MgO}$ in the form of $\mathrm{Mg}^{+2}$ ions. These ions are further complexed in the form of $\mathrm{Mg}\left(\mathrm{H}_{2} \mathrm{O}\right)_{6}^{+2}$ ions, replacing the adsorbed $\mathrm{H}_{2} \mathrm{O}$ molecules on the surface of the basic oxide $(\mathrm{MgO})$. The hydrated phases form only after a complex between these $\mathrm{Mg}\left(\mathrm{H}_{2} \mathrm{O}\right)_{6}{ }^{+2}$ ions and those from the $\mathrm{ADP}\left(\mathrm{PO}_{4}^{-3}\right.$ and $\left.\mathrm{NH}_{4}^{+}\right)$form, followed by solubilization 
and then nucleation and growth reactions. That is, a higher concentration of $\mathrm{Mg}\left(\mathrm{H}_{2} \mathrm{O}\right)_{6}^{+2}$ for a fixed concentration of $\mathrm{PO}_{4}^{-3}$ and $\mathrm{NH}_{4}^{+}$(of ADP) leads to the formation of more nuclei and smaller crystals. Increasing the amount of water is known to facilitate the dissolution of $\mathrm{MgO}$, which would increase the concentration of the $\mathrm{Mg}^{+2}$ ions. The concentration of $\mathrm{PO}_{4}^{-3}$ and $\mathrm{NH}_{4}{ }^{+}$ions was unchanged because the $\mathrm{MgO} / \mathrm{ADP}$ ratio was fixed when the amount of water within a given

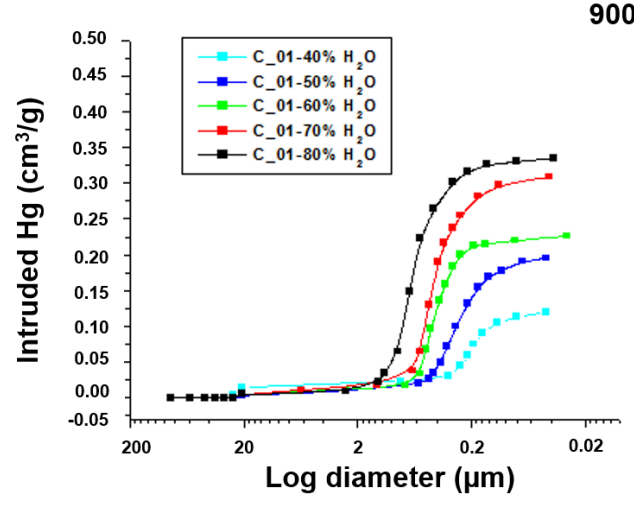

(A)

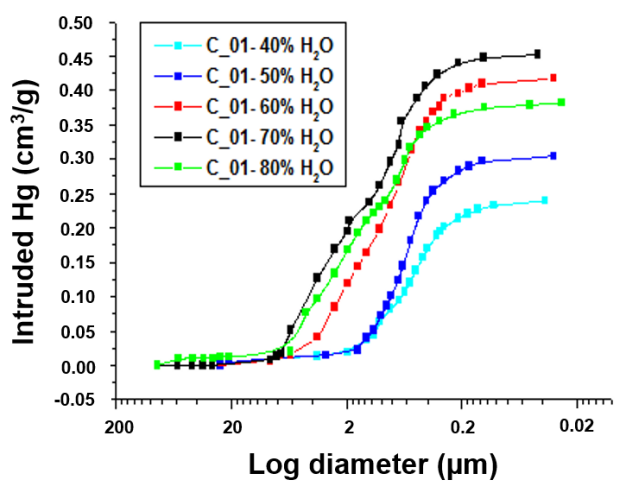

(C) $900^{\circ} \mathrm{C} / 2 \mathrm{~h}$

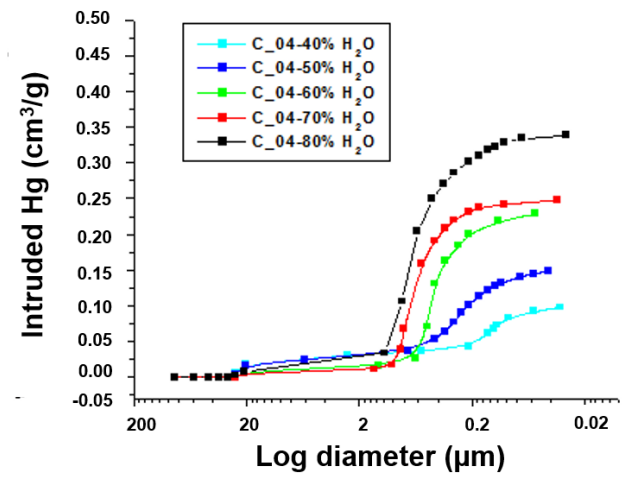

(B)

$1100^{\circ} \mathrm{C} / 2 \mathrm{~h}$

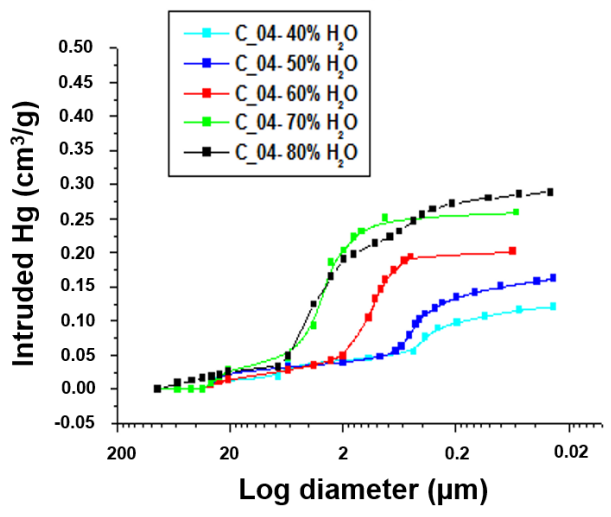

(D)

Figure 7. Effect of water content on the pore size distributions of compositions (A) and (B) containing $\mathrm{MgO}$ powders calcined at $900{ }^{\circ} \mathrm{C} / 2 \mathrm{~h}$ and (C) and (D) containing $\mathrm{MgO}$ powders calcined at $1100{ }^{\circ} \mathrm{C} / 2 \mathrm{~h}$.
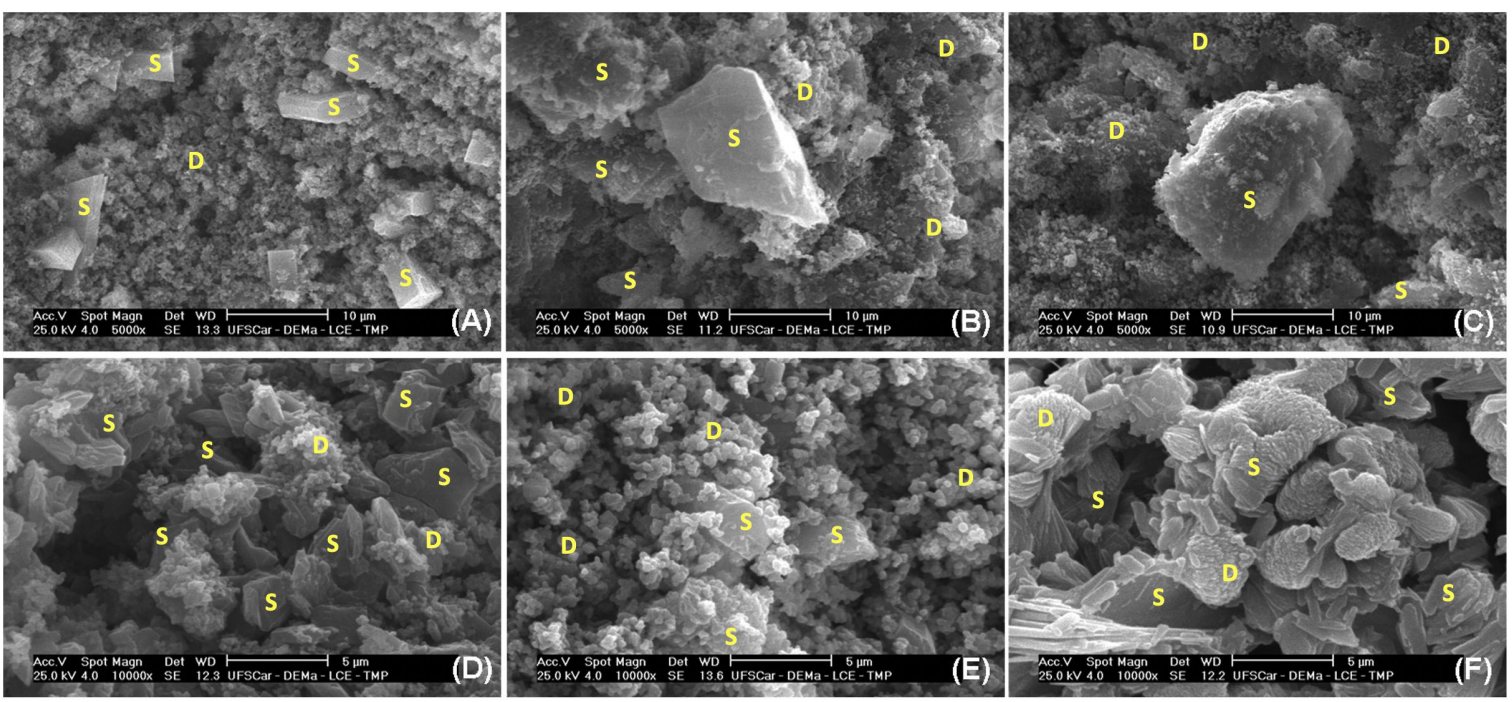

Figure 8. Microstructure of samples (A) $\mathrm{C} 01-40 \% \mathrm{H}_{2} \mathrm{O}$; (B) $\mathrm{C} \_01-60 \% \mathrm{H}_{2} \mathrm{O}$; (C) $\mathrm{C} 01-80 \% \mathrm{H}_{2} \mathrm{O}$; (D) $\mathrm{C}_{-} 04-40 \% \mathrm{H}_{2} \mathrm{O}$; (E) C_04 - 60\% $\mathrm{H}_{2} \mathrm{O}$; and (F) C_04 - 80\% $\mathrm{H}_{2} \mathrm{O}$ prepared using $\mathrm{MgO}$ powders calcined at $900{ }^{\circ} \mathrm{C} / 2 \mathrm{~h}$. (Struvite phase $-\mathrm{S}$; dittmarite phase - D) 

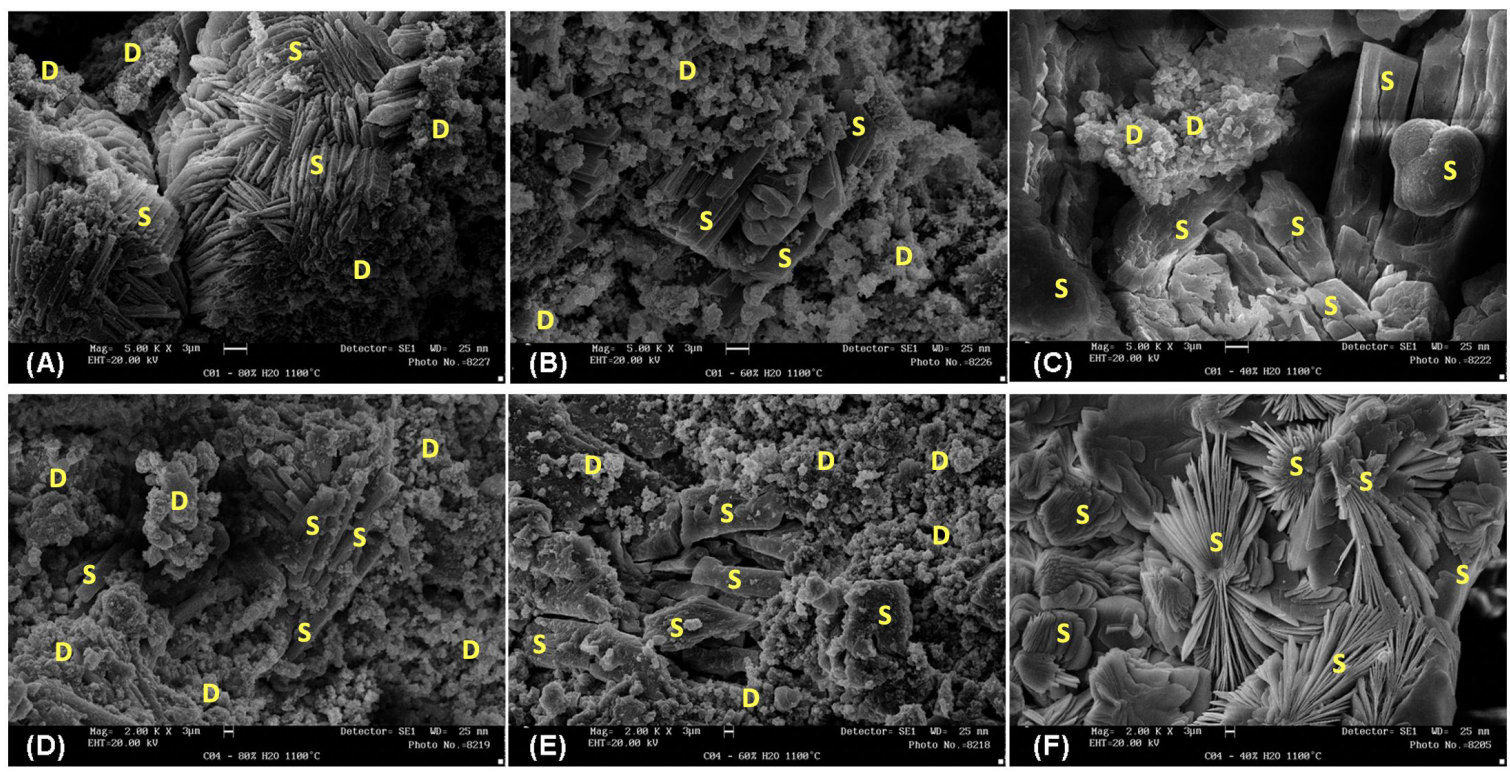

Figure 9. Microstructure of samples (A) C_01 - $40 \% \mathrm{H}_{2} \mathrm{O}$; (B) C_ $01-60 \% \mathrm{H}_{2} \mathrm{O}$; (C) C_01 - 80\% $\mathrm{H}_{2} \mathrm{O}$; (D) C_04 - $40 \%$ H $\mathrm{O}$; (E) C_04 - 60\% $\mathrm{H}_{2} \mathrm{O}$; and (F) C_04 - $80 \% \mathrm{H}_{2} \mathrm{O}$ prepared using $\mathrm{MgO}$ powders calcined at $1100{ }^{\circ} \mathrm{C} / 2 \overline{\mathrm{h}}$. (Struvite phase $-\overline{\mathrm{S}}$; dittmarite phase $-\overline{\mathrm{D}}$ )

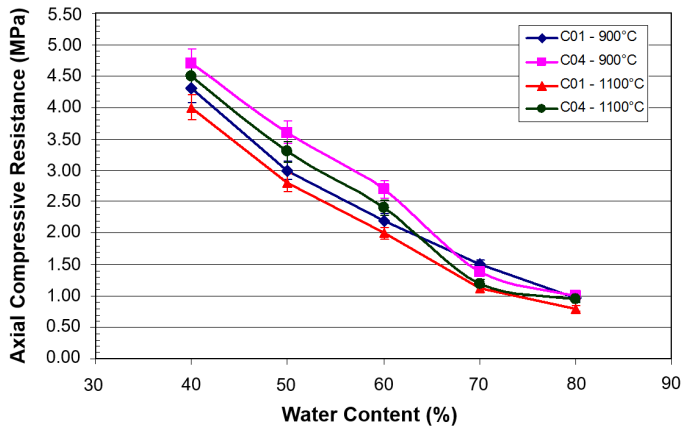

Figure 10. Axial compressive mechanical strength of magnesium phosphate cement compositions $\mathrm{C} 01$ and $\mathrm{C} 04$, which were prepared using $\mathrm{MgO}$ powders calcined at $900^{\circ} \mathrm{C} / 2 \mathrm{~h}$ and $1100{ }^{\circ} \mathrm{C} / 2 \mathrm{~h}$, as a function of water content.

composition was varied, resulting in a decrease in the size of the struvite $\left(\mathrm{NH}_{4} \mathrm{MgPO}_{4} \cdot 6 \mathrm{H}_{2} \mathrm{O}\right)$ crystals due to an increase in the amount of water.

For composition C_ 04 consisting of $40 \% \mathrm{H}_{2} \mathrm{O}$, its struvite $\left(\mathrm{NH}_{4} \mathrm{MgPO}_{4} \cdot 6 \mathrm{H}_{2} \mathrm{O}\right)$ had a structure that was more fragile than that of compositions with higher water contents. At these conditions, there is a shortage of both water and time for the formation of the hydrated phases, which could lead to the formation of phases with lower crystallinity. The dittmarite $\left(\mathrm{NH}_{4} \mathrm{MgPO}_{4} \cdot \mathrm{H}_{2} \mathrm{O}\right)$ phase was also observed near the struvite $\left(\mathrm{NH}_{4} \mathrm{MgPO}_{4} \cdot 6 \mathrm{H}_{2} \mathrm{O}\right)$ crystals.

According to the results of the mechanical resistance tests (Figure 10), samples calcined at $900{ }^{\circ} \mathrm{C}$ had higher reactivity and superior mechanical resistance than that of samples calcined at $1100{ }^{\circ} \mathrm{C}$, regardless of the added water content. A gradual reduction of the mechanical resistance was also observed due to the increase in water content because of higher porosity (Figure 9), which also explains the higher mechanical resistance values for the $\mathrm{C} 04$ compositions (lower $\mathrm{MgO} / \mathrm{NH}_{4} \mathrm{H}_{2} \mathrm{PO}_{4}$ ). As previously discussed, dittmarite $\left(\mathrm{NH}_{4} \mathrm{MgPO}_{4} \cdot \mathrm{H}_{2} \mathrm{O}\right)$ is the dominant phase when the reaction is fast, whereas struvite $\left(\mathrm{NH}_{4} \mathrm{MgPO}_{4} \cdot 6 \mathrm{H}_{2} \mathrm{O}\right)$ dominates when the reaction is slow ${ }^{32}$; thereby dittmarite is more resistant than struvite. These results are in accordance with the XRD and FTIR results (Figures 4 and 5).

The binder content significantly influences the setting and hardening of the material, whereas its strength influences the mechanical properties ${ }^{33,34}$. The amount of phosphate hydrates surrounding the $\mathrm{MgO}$ grains increases with the amount of $\mathrm{NH}_{4} \mathrm{H}_{2} \mathrm{PO}_{4}$ present, consequently increasing the strength of the $\mathrm{MPC}^{35-37}$

However, several studies have shown results contrary to those presented in Figure 10. Sugama and Kukacka ${ }^{38}$ studied the effect of the $\mathrm{MgO} / \mathrm{ADP}$ ratio on the mechanical strength of magnesium phosphate cements and observed that the higher the amount of $\mathrm{MgO}$ (higher $\mathrm{MgO} / \mathrm{ADP}$ ratio), the higher the mechanical resistance to compression. The same behavior was observed by Yang and $\mathrm{Wu}^{27}$ as well as Sant'Anna and Morelli ${ }^{15}$. These studies suggest that the non-solubilized $\mathrm{MgO}$ particles are the skeleton of the cement structure, which is why higher concentrations of $\mathrm{MgO}$ offered better mechanical resistance. Yang and $\mathrm{Wu}^{27}$ also stress that the mechanical strength of the remaining $\mathrm{MgO}$ grains is much higher than the strength of the hydrated phases, although it was stated that the concentration of the hydrated phases should be high enough to bind the $\mathrm{MgO}$ grains.

\section{Conclusions}

Considering the analysis of the results obtained from the experimental conditions adopted for this study, the following can be concluded:

- A higher calcination temperature is associated with a greater crystallite size, higher average particle size, 
and more crystalline $\mathrm{MgO}$ powders; although these powders had lower reactivity due to a reduction in the surface area.

- $\quad$ For the less reactive samples (calcined at $1100^{\circ} \mathrm{C}$ ) with a high $\mathrm{MgO} / \mathrm{NH}_{4} \mathrm{H}_{2} \mathrm{PO}_{4}$ ratio, an increase in the water content did not lead to additional solubilization of ADP or the formation of more hydrated phases, although the porosity of the cement increased.

- Compositions containing $\mathrm{MgO}$ with a higher reactivity (calcined up to $900{ }^{\circ} \mathrm{C}$ ) and lower $\mathrm{MgO} / \mathrm{NH}_{4} \mathrm{H}_{2} \mathrm{PO}_{4}$ ratio present a tendency to form dittmarite $\left(\mathrm{NH}_{4} \mathrm{MgPO}_{4} \cdot \mathrm{H}_{2} \mathrm{O}\right)$ and increases the mechanical strength independent of water content, and present a gradual reduction in the mechanical strength as a consequence of the increase in water content due to higher porosity.

- A higher water content and calcination temperature of $\mathrm{MgO}$ were associated with a longer MPC setting time.

\section{Acknowledgments}

CNPq - National Counsel of Technological and Scientific Development (Brazil)

\section{References}

1. Maldonado-Alameda A, Lacasta AM, Giro-Paloma J, Chimenos JM, Haurie L, Formosa J. Magnesium phosphate cements formulated with low grade magnesium oxide incorporating phase change materials for thermal energy storage. Constr Build Mater. 2017;155:209-216.

2. Ma H, Xu B, Liu J, Pei H, Li Z. Effects of water content, magnesia-to-phosphate molar ratio and age on pore structure, strength and permeability of magnesium potassium phosphate cement paste. Mater Des. 2014;64:497-502.

3. Liu Y, Qin Z, Chen B. Experimental research on magnesium phosphate cements modified by red mud. Constr Build Mater. 2020;231:117-31.

4. Green J. Calcination of precipitated $\mathrm{Mg}(\mathrm{OH})_{2}$ to active $\mathrm{MgO}$ in the production of refractory and chemical grade $\mathrm{MgO}$. J Mater Sci. 1983;18(3):637-51.

5. Birchal VSS, Rocha SDF, Ciminelli VST. The effect of magnesite calcination conditions on magnesia hydration. Miner Eng. 2000;13(14-15):1629-33.

6. Argonne National Laboratory. Chemically bonded phosphate ceramics: cementing the gap between ceramics, cements and polymers. Albany, OR: National Energy Technology Laboratory; 2020 [cited 2020 Mar 15]. Available from: http://www.netl.doe. gov/kmd/CDs/Disk17/C\%20-\%20Drilling\%20Completion $\% 20$ Stimulati on/FEWAA055\%20Paper\%202002\%20Jun.pdf

7. Sarkar AK. Phospate cement-based fast-setting binders. Ceramic Bulletin. 1990;69(2):234-7.

8. Kingery W. Fundamental studies of phosphate bonding in refractories, II. Cold setting properties. J Am Ceram Soc. 1951;33:242-7.

9. Sugama T, Kucacka LE. Magnesium monophosphate cements derived from diammonium phosphate solutions. Cement Concr Res. 1983;13:407-16.

10. Sugama T. Strenght development in phosphate bonded calcium aluminate cements. J Am Ceram Soc. 1991;74(5):1023-30.

11. Ribeiro DV, Morelli MR. Influence of the addition of grinding dust to a magnesium phosphate cement matrix. Constr Build Mater. 2009;23:3094-102.
12. Soudée E, Péra J. Mechanism of setting reaction in magnesia - phosphate cements. Cement Concr Res. 2000;30:315-21.

13. Abdelrazig BEI, El-Jazairi B. The chemical composition of mortars made from magnesia-phosphate cement. Cement Concr Res. 1988;18:415-25.

14. Abdelrazig BEI, El-Jazairi B. The microstructure and mechanical properties of mortars made from magnesia - phosphate cement. Cement Concr Res. 1989; 19:247-58.

15. Sant'Anna JAP, Morelli MR. Chemically bonded MgO mouldable ceramics. Acta Microscopia, 1998;7:41-44.

16. Qin J, Qian J, You C, Fan Y, Li Z, Wang H. Bond behaviour and interfacial micro-characteristics of magnesium phosphate cement onto old concrete substrate. Constr Build Mater. 2018;167:166-76.

17. Lu X, Chen B. Experimental study of magnesium phosphate cements modified by metakaolin. Constr Build Mater. 2016;123:719-26.

18. Xu B, Lothenbach B, Leemann A, Winnefeld F. Reaction mechanism of magnesium potassium phosphate cement with high magnesium-to-phosphate ratio. Cement Concr Res. 2018;108:140-51.

19. Ribeiro DV, Paula GR, Morelli MR. Effect of boric acid content on the properties of magnesium phosphate cement. Constr Build Mater. 2019;214:557-64.

20. Ribeiro, DV, Paula, GR, Morelli MR. Effect of MgO/NH4H2PO4 ratio on the properties of magnesium phosphate cement. Mat Res. 2020;23(2):e20200034. https://doi.org/10.1590/19805373-mr-2020-0034

21. Ribeiro DV, Paula GR, Morelli MR. Use of microwave oven in the calcination of $\mathrm{MgO}$ and effect on the properties of magnesium phosphate cement. Constr Build Mater. 2019;198:619-28.

22. Pilarska AA, Klapiszewski Ł, Jesionowski T. Recent development in the synthesis, modification and application of $\mathrm{Mg}(\mathrm{OH})_{2}$ and MgO: a review. Powder Technol. 2017;319:373-407.

23. Ribeiro DV, Agnelli JAM, Morelli MR. Study of mechanical properties and durability of magnesium phosphate cement matrix containing grinding dust. Mater Res. 2013;16:1113-21.

24. Rezaei M, Khajenoori M, Nematollahi B. Preparation of nanocrystalline $\mathrm{MgO}$ by surfactant assisted precipitation method. Mater Res Bull. 2011;46(10):1632-7.

25. Sonat C, Lim CM, Liska M, Unluer C. Recycling and reuse of reactive $\mathrm{MgO}$ cements $-\mathrm{A}$ feasibility study. Constr Build Mater. 2017;157:172-81.

26. Hall DA, Stevens R. Effect of water content on the structure and mechanical properties of magnesia - phosphate cement mortar. J Am Ceram Soc. 1998;81(6):1550-6.

27. Yang Q, Wu X. Factors influencing properties of phosphate cement - based binder for rapid repair of concrete. Cement Concr Res. 1999;29:389-96.

28. Ribeiro DV, Agnelli JAM, Morelli MR. Study of mechanical properties and durability of magnesium phosphate cement matrix containing grinding dust. Mater Res. 2013;16:1113-21.

29. Ribeiro DV, Morelli MR. Performance analysis of magnesium phosphate cement mortar containing grinding dust. Mater Res. 2009;12:51-6.

30. Péra J, Soundée E. Influence of magnesia surface on the setting time of magnesia phosphate cement. Cement Concr Res. 2002;32:153-7.

31. Kingery WD, Francois B. Sintering of crystalline oxides, I: interection between grain boundaries and pores. In: Kuczynski GC, editor. Sintering and related phenomena. New York: Gordon and Breach; 1967. p. 8.

32. Sarkar AK. Hydration/dehydration characteristics of struvite and dittmarite pertaining of magnesium ammonium phosphate cement systems. J Mater Sci. 1991;26(12):2514-8.

33. Arnaud L, Gourlay E. Experimental study of parameters influencing mechanical properties of hemp concretes. Constr Build Mater. 2012;28:209-16. 
34. Del Valle-Zermeño, R., Aubert, JE, Laborel-Préneron A, Formosa J, Chimenos JM. Preliminary study of the mechanical and hygrothermal properties of hempmagnesium phosphate cements. Constr Build Mater, 2016;105:62-68.

35. Wagh A, Strain R, Jeong S, Reed D, Krouse T, Singh D. Stabilization of rocky flats Pu-contaminated ash within chemically bonded phosphate ceramics. J Nuclear Materials. 1999;265:295-307.
36. Qin J, Qian J, You C, Fan Y, Li Z, Wang H. Bond behavior and interfacial micro-characteristics of magnesium phosphate cement onto old concrete substrate. Constr Build Mater. 2018;167:166-76.

37. Lu X, Chen B. Experimental study of magnesium phosphate cements modified by metakaolin. Constr Build Mater. 2016;123:719-26.

38. Sugama T, Kucacka LE. Characteristics of magnesium polyphosphate cements derived from ammonium polyphosphate solutions. Cement Concr Res. 1983;13:499-506. 